\title{
SORTING OF OLIVE FRUITS USING VISIBLE LASER ACCORDING TO COLOR
}

\author{
H. E. Hassan *
}

\begin{abstract}
The aim of this research is to measure and determine the physical, optical and electrical properties for mature olive fruits using visible laser, and to make prototype for sorting olive fruits using visible laser. The experimental setup was made at the Institute of Laser Enhanced Science (NILES), Cairo University, Giza, Egypt. The obtained results were as follows: 1) The greatest length of the olive was $(3.3 \mathrm{~cm})$ and least width $(1.7 \mathrm{~cm})$ of olive, were used to make the width and height sides of transporter channel to suit exposing the fruit to laser beam, 2) The highest and lowest percentages of reflection light intensity were 0.82 $\%$ and $0.52 \%$ for surface of green and black olive fruit, respectively. So, the sorting prototype was depending on $0.82 \%$ reflection for sorting green olive from olive maturity fruit, 3) The highest and lowest electrical signals resulted from reflection light intensity of 23.9 and $14.6 \mathrm{mV}$ for green and black olive fruit, respectively. So, the sorting prototype depended on equal or more than $22.4 \mathrm{mV}$ of electrical signals for sorting green olive from olive maturity fruit, 4) It is prefer able to use feeding rate of $394.61 \mathrm{~g} / \mathrm{min}$ during operating time of $5.07 \mathrm{~min}$ with separating efficiency of $95 \%$, because it gave the lowest cost per operating unit in comparison with other cost operating unit of prototype, and 5) Separation efficiency of manual $96 \%$ is higher than separating efficiency of $95 \%$ of prototype, and cost operating unit of manual 0.85 L.E. is lower than cost of operating unit of prototype of 1.39 L.E. However, working time of prototype $5.07 \mathrm{~min}$ is lower than working time of manual 13.68min. So, it is preferable to use the prototype for sorting of mature olive fruit with large scale and high accuracy.
\end{abstract}

\footnotetext{
* Assoc. Prof., Nat. Inst. of Laser Enhanced Sc. (NILES), Cairo Univ., Egypt.
} 


\section{INTRODUCTION}

$\mathbf{L}$ oudiyi et al. (1984) decided that the olives were picked according to skin color from all round the perimeter of the trees. The color sequence was green (G), light-green (LG), small reddish spots (SRS), turning-color (TC), purple (P) and black (B), from the first to the last sampling, respectively.

García et al. (1996) observed that the non-destructive techniques can improve handling at the olive mills because the quality characteristics of the olive fruit would be determined beforehand. In addition, these techniques could allow monitoring quality attributes of large amounts of the olive fruit.

Abbott (1999) suggests the use of optical methods to follow the maturation process, as applied to other kinds of fruits. Spectroscopic techniques can assess rapidly and nondestructively both photosynthetic and accessory pigments in fruits.

Psomiadou and Tsimidou (2001) reported that significant differences between cultivars $(p<0.001)$ were also observed in pigment contents. The presence of the pigment in the oil depends on several factors, such as the olive cultivar, soil and climatic conditions, fruit ripeness and the processing procedures.

Roca and Minguez-Mosquera (2001) clearly showed that the olive fruit, Olea europaea, during the ripening process, darkens to purple-black at the same time as the oil content increases. As ripening progresses, photosynthetic activity decreases and the concentrations of both chlorophylls and carotenoids decrease progressively. At the end of the maturation process, the violet or purple colour of the olive fruit is due to the formation of anthocyanins.

Ounis et al. (2001) mentioned that the fluorescence intensity emitted by the chloroplasts in the Mesophyll for olive quality is dependent on the amount of light reaching them, because the UV radiation is much more attenuated with respect to visible light in the epidermal layers.

Mulinacci et al. (2001) observed that, there is much interest in developing agronomic techniques that maximize particular classes of olive phenolics. Several factors affect the phenolic composition and 
quality in olive fruits, such as cultivar, growing site, climatic conditions, alternate bearing, and ripening stage.

Ryan et al. (2002) showed that indeed, fruit ripening is accompanied by a change in the skin color due to a modification of pigment concentration in the superficial tissues. Usually, color development from green to purple is modulated by an accumulation of anthocyanins (Anths) together with the degradation of chlorophylls (Chls) and carotenoids .

Jaakola et al. (2002) mentioned that the Anths are suitable for in situ spectroscopic detection since they accumulate in the outer layers of olives and present a characteristic absorption band in the green region around $530 \mathrm{~nm}$.

León et al. (2004) reported that the Near Infrared Spectroscopy as a useful tool in olive breeding programs, using it for analysis of oil content ( $\mathrm{SEC}=1.33)$, moisture $(\mathrm{SEC}=1.88)$ and fatty acid composition in intact olive with spectral range $400-1700 \mathrm{~nm}$.

Diaz et al. (2004) observed that the external appearance of an olive's skin is the most decisive factor in determining its quality as a fruit. This work tries to establish a hierarchical model based on the features extracted from images of olives reflecting their external defects.

Peter et al. (2005) mentioned that the developments in the field of noninvasive techniques for quality analysis of fresh fruit and vegetables. The concept of quality is followed by a discussion of various methods and applications including optical, spectroscopic, and mechanical techniques, also the application of X-rays and some noninvasive methods of minor dispersal.

Giovanni et al. (2005) measured the Anthocyanins (Anths) in olive (Olea europaea L.) fruits at different degrees of pigmentation were assessed nondestructively by measuring chlorophyll fluorescence (ChlF). The method is based on the comparison of the ChlF excitation spectra from olives with different pigmentation from green to green-red, reddishpurple, and purple.

Nicolai et al. (2007) mentioned that the techniques that enable the monitoring of the oil content in the olive fruit at different stages of maturity would be useful. However Near Infrared Spectroscopy (NIRS) is used for determining internal quality of intact fruit. 
Riquelme et al. (2008) mentioned that the external appearance of an olive's skin is the most decisive factor in determining its quality as a fruit. Seven commercial categories of olives, established by product experts, were used. The original images were processed using segmentation, colour parameters and morphological features of the defects and the whole fruits.

Garc et al. (2008) used the electro spray ionization mass spectrometry to predict the olive oil quality according to European Union marketing standards. Samples were 1:50 diluted in an alkaline 85:15 (v/v) propanol/methanol mixture and directly infused into the electrospray ionization source of an ion trap mass spectrometer. The establishment of ratios of the peak abundances of the free fatty acids followed by linear discriminant analysis was employed to predict the olive oil quality grade. Jose et al. (2010) investigated the intact olive fruit quality prediction parameters measured directly by visible and near infrared spectroscopy (Vis/NIRS). The analysed parameters of the olive fruits were moisture, dry matter, oil content, oil free acidity and fruit maturity index.

Hassan et al. (2011) divided the olive fruit into five stages during maturity according to color component values (RGB), which can be used for sorting and grading. Classifying olive maturity according to color properties (HSB) during harvesting time was (77.32, 56.74 and 70.96), (57.08, 33.06 and 70.84), (22.36, 40.08 and 81.54) and (329.0, 8.78 and 19.34) for stages 1, 2, 3, 4 and 5., respectively.

Jia et al. (2012) mentioned that today, the researches on fruit surface defects are focused on defects detection, but hardly focused on defects classification, where on the basis of determining defect area correctly, the paper is focused on surface defects classification in order to meet the requirements of grading standards, then achieve automatic fruits classification .

The aims of this study are:

1- Measurement and determination of the physical and optical properties for maturity of olive fruits using visible laser.

2- To sort olives into two classes, according to the external color of olives fruits.

3- To develop a prototype for sorting olive fruits using visible laser. 


\section{MATERIAL AND METHODS}

This study was executed at the Laboratory of Laser Application in the Agricultural Engineering at the National Institute of Laser Enhanced Science (NILES), Cairo University, Egypt. The experiments and measurements for the optical properties of olive were carried out according to the following procedures:

Fruit sample: Random samples of ten kilograms olive fruits (kronaki) from the production farm at Ismaelia Governorate, Egypt. Sampling of olives with different color fruit were picked during harvesting season. The following parameters were measured: olive mass, main dimensions; optical and electrical properties using visible laser.

\section{Physical measurements:}

Digital balance: One type of digital balance was used in the present investigation: Source of manufacture is Germany, accuracy $0.01 \mathrm{~g}$ and maximum measurement, $4100 \mathrm{~g}$. It was used to determine the mass of each olive.

Digital vernier caliper: Digital vernier caliper with an accuracy of 0.01 $\mathrm{mm}$ was used to measure the different dimensions: length $(\mathrm{L})$ and width (W) for olive fruit.

Friction coefficient device: The device was used to measure friction angle for galvanized, iron, fiber, plastic and wood material sheets with applied in friction coefficient equation: friction coefficient $=1 / \tan \theta \ldots$ (1)

\section{Optical and electrical measurements:}

Experimental setup, consisted of laser source, holders, convex lens, photovoltaic cell, luxmeter and avometer, as shown in Fig. (1).

Laser, the helium-neon (He-Ne) lasers with wavelength $543.5 \mathrm{~nm}$ (visible light) and power $4 \mathrm{~mW}$ was used in the present work as a light source. The He-Ne laser was used in optical and electrical properties of olive fruits and sorting prototype. The specifications of the laser used in the present work are shown in table (1).

Holders, were designed and fabricated of copper to hold beam expander, photo voltaic cell and grading detector.

Lens, glass lens of $100 \mathrm{~mm}$ focal length with diameter $75 \mathrm{~mm}$ was used to collect reflection light into luxmeter detector. 
Photovoltaic cell, the photovoltaic cell is 60 and $40 \mathrm{~mm}$ length and width, respectively. Its efficiency is about $32 \%$. Photocell was mounted on a holder in front of the olive fruit with angle 45 degree for received reflection from surface olive fruit. The intensity of the reflected light is transformed to voltage by photovoltaic cells which were connected directly to an avometer.

Table (1): specifications of Helium-Neon laser.

\begin{tabular}{|l|l|}
\hline Item & Wavelength $543.5 \mathrm{~nm}$. \\
\hline Source of manufacture & USA \\
Model & 05- LGR-173 \\
Type & Gas laser \\
Wavelength, nm & 543.5 \\
Beam & Continuous wave \\
Output power, mW & 4 \\
Beam diameter, mm & 0.75 \\
Beam divergence, mrad & 0.92 \\
Polarization ratio & Random \\
Mass, kg & 0.61 \\
Input current, Ac, Amp. & 220,3 \\
Operating temperature, ${ }^{\circ} \mathrm{C}$ & -20 to +50 \\
Storage temperature, ${ }^{\circ} \mathrm{C}$ & -40 to +80 \\
\hline
\end{tabular}

Digital Luxmeter, a digital luxmeter with high accuracy and sensitivity was used to measure the intensity of reflection from olive surface. Digital Luxmeter specifications are shown in table (2).

Table (2): Specifications of the digital Luxmeter.

\begin{tabular}{|l|l|l|}
\hline No. & Items & Luxmeter Specifications \\
\hline 1 & Source of manufacture & Japan \\
2 & Model & Lx-101 \\
3 & Ranges, Lux & $0-50,000$ (3 ranges) \\
4 & Power supply, V, mA & 9,2 \\
5 & Dimensions $\left(L^{*} \mathrm{~W}^{*} \mathrm{H}\right), \mathrm{mm}$ & $108 \times 73 \times 23$ \\
\hline
\end{tabular}

L: Length, W: Width and H: Height.

Avometer, a digital multi-meters model CDA-701, with accuracy of 0.1 $\mathrm{mV}$, measuring range $1 \mathrm{mV}$ to $1000 \mathrm{~V}$ (DC), made in Japan. The 
avometer was used to measure the electrical signal with voltage which resulted from converted reflection of light from olive fruit surface by a photovoltic cell.

The light received is converted into voltage by photovoltaic cell, which was connected directly to an avometer in order to measure electrical signals from surface of olive fruits.

\section{Optical and electrical measurements:}

The olive fruit surface is exposed to the laser beam, then the reflected intensity was collected by convex lens (glass lens of $100 \mathrm{~mm}$ focal length with diameter $75 \mathrm{~mm}$ ) and measured by luxmeter detector. After measuring intensity of reflection without transmission of incident beam, the absorption of olive fruit was calculated according to the law of conservation of energy from the following equation:

$$
\mathrm{I}=\mathrm{R}+\mathrm{A}
$$

Where: $\mathrm{I}$ is the incident beam, Lux; $\mathrm{R}$ - reflective beam, Lux; and

A- absorptive beam, Lux.

\section{Sorting unit:}

Sorting unit was fabricated in the workshop of the institute and consists of the following items as shown in Fig. and photo (3):

1- Fruit feeding hopper, with cone shape of dimensions $15 \times 15 \times 30 \mathrm{~cm}$ and capacity of about 2000 gram. It was fabricated of iron sheet with thickness $1 \mathrm{~mm}$.

2- Feeding wheel, with diameter $8 \mathrm{~cm}$ divided into four hollows for four olive fruits (one fruit / hollow). It was fabricated from plastic sheet with thickness of $3 \mathrm{~cm}$. It operates by feeding wheel motor.

3- Rolling Channel, with dimension $50 \times 3 \times 1 \mathrm{~cm}$ and capacity 25 olive fruits. It was fabricated from iron sheet with thickness $1 \mathrm{~mm}$.

4- Light source, the helium-neon (He-Ne) laser was used with wavelength $543.5 \mathrm{~nm}$ (visible light) and power $4 \mathrm{~mW}$.

5- Photovoltaic cell, the photovoltaic cell was mounted on a holder in front of the olive fruit with angle 45 degree for receiving reflection from surface olive fruit. The intensity of the reflected light is transformed to low voltage by photovoltaic cells which were connected with amplifying circuit to amplify signals to operate a separating fan. 
6- Separation fan, with diameter $8 \mathrm{~cm}$ and connected with two arms for bushing the green olive fruit inside basket. It fabricated in plastic sheet with thickness $0.5 \mathrm{~cm}$. It operates by Separator motor.

7- Power supply, relay circuit as an electric amplification as shown in Fig. (2). The electrical signals coming from photovoltaic cell which corresponds to beam reflection from olive surface through to power supply which converts this signals from $22.4 \mathrm{mV}$ to $220 \mathrm{~V}$ to suit the electrical motor of separating fan as an ejector.

8- Fruit collection, two plastic baskets, one for black olive and the other for green fruit.

9- Motors, two synchronous motors were used in the sorting prototype. One motor for feeding wheel and the other for separating fan of olive fruit. Specification of motors was as follow in table (3).

Table (3): Specification of motors.

\begin{tabular}{|l|l|l|}
\hline Items & Feeding wheel motor & Separator motor \\
\hline Model & PGM-123 (Fast) & PGM - 125 (Slow) \\
\hline Motor speed, rpm & $30-36$ & $5-6$ \\
\hline Electric power, V & 220 & 220 \\
\hline Frequency, Hz & $50 / 60$ & $50 / 60$ \\
\hline Made in & China & China \\
\hline
\end{tabular}

\section{Operating cost of the unit:}

The total cost was determined by using the following equation (Awady, 1978): $\quad C=p / h(1 / a+i+t / 2+r)+(E c \times E p)+m / 144$

Where: - C : Operation hourly cost, L. E / h

- $p$ : Price of machinery, L. E.

- $\mathrm{h}$ : Yearly working hours, $\mathrm{h} /$ year

- a : Life-expectancy of machines in years, year

- i : Interest rate, L.E./year

- $\mathrm{t}$ : Taxes ratio, L.E./year

- $\quad \mathrm{r}$ : Overhead and indirect cost ratio, L.E./year

- Ec: Electricity energy consumption, $\mathrm{kW} / \mathrm{h}$

- Ep: Electricity price , L.E./kW.h

- $\mathrm{m}$ : Monthly average wage, L.E.

- 144: The estimated working, $\mathrm{h} /$ month.

Operation unit cost, $(\mathrm{L} . \mathrm{E} / \mathrm{g})=$ prototype cost $(\mathrm{L} . \mathrm{E} / \mathrm{h}) /$ Productivity $(\mathrm{g} / \mathrm{h})$.. (3) 


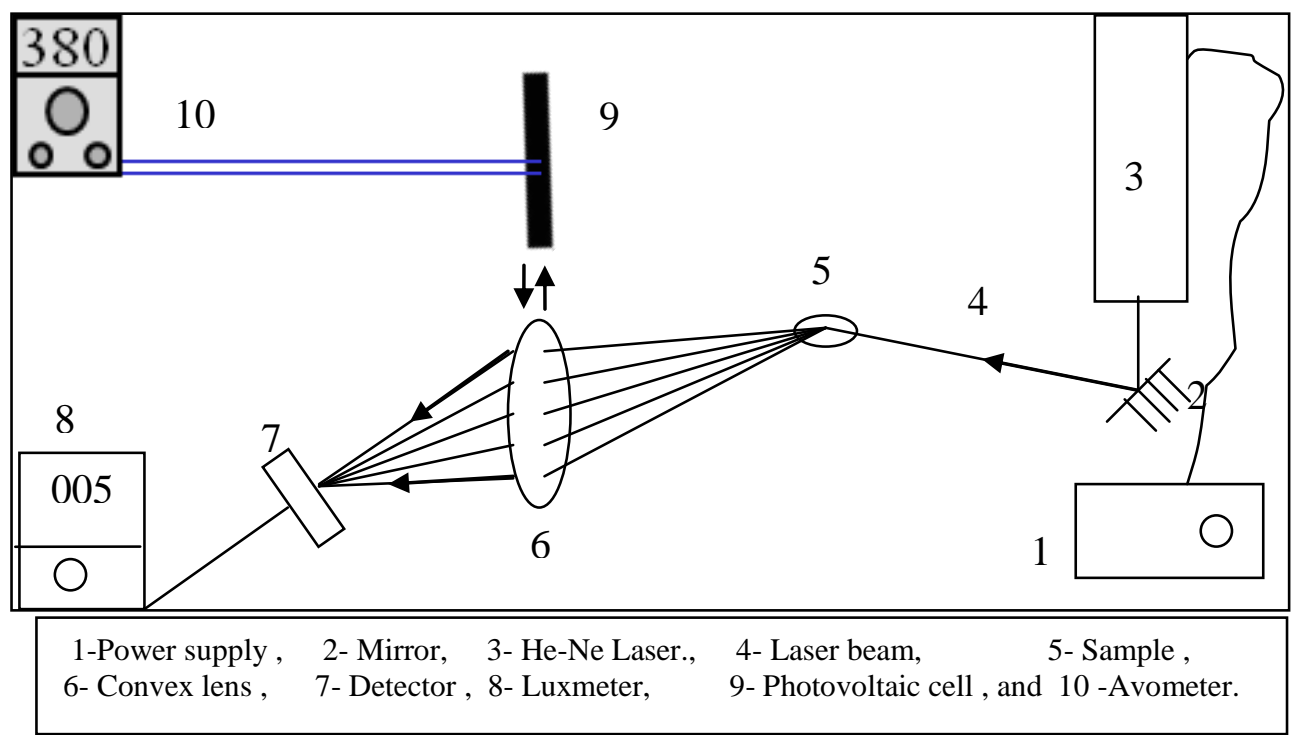

Fig. (1) : Schematic diagram of experimental setup for measuring the optical properties of olive fruits.

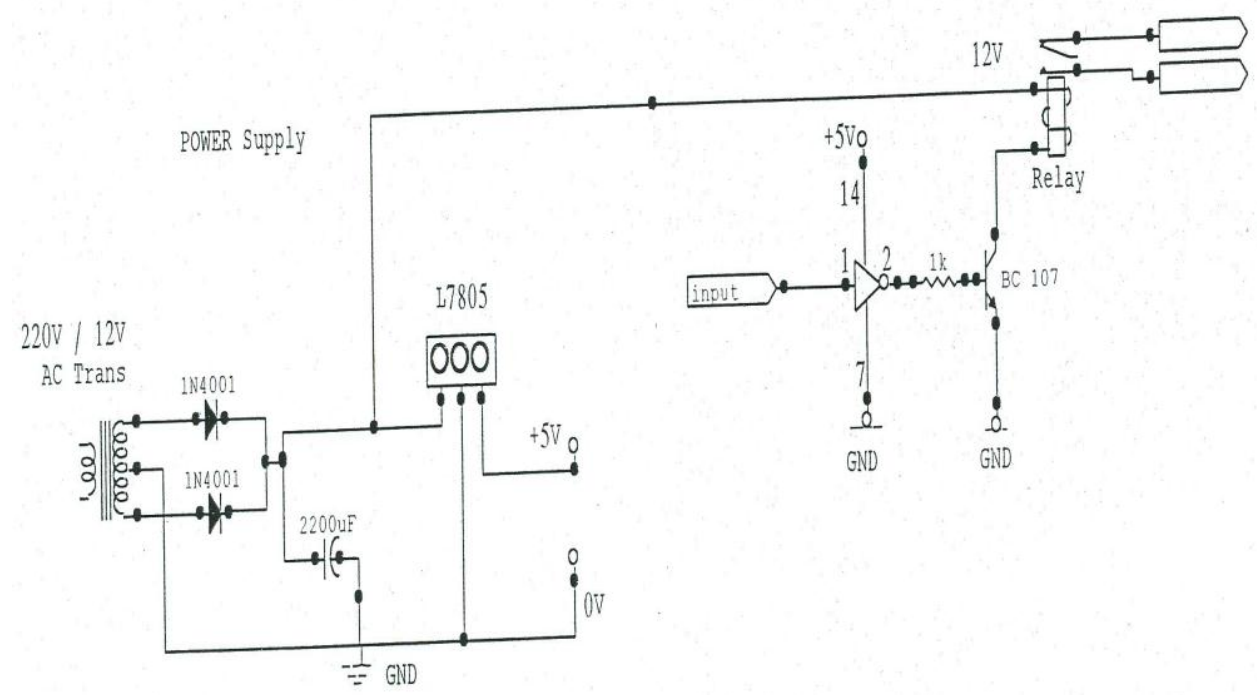

Fig. (2) : Power supply, relay circuit of sorting unit for olive fruits . 


\section{PROCESS ENGINEERING}

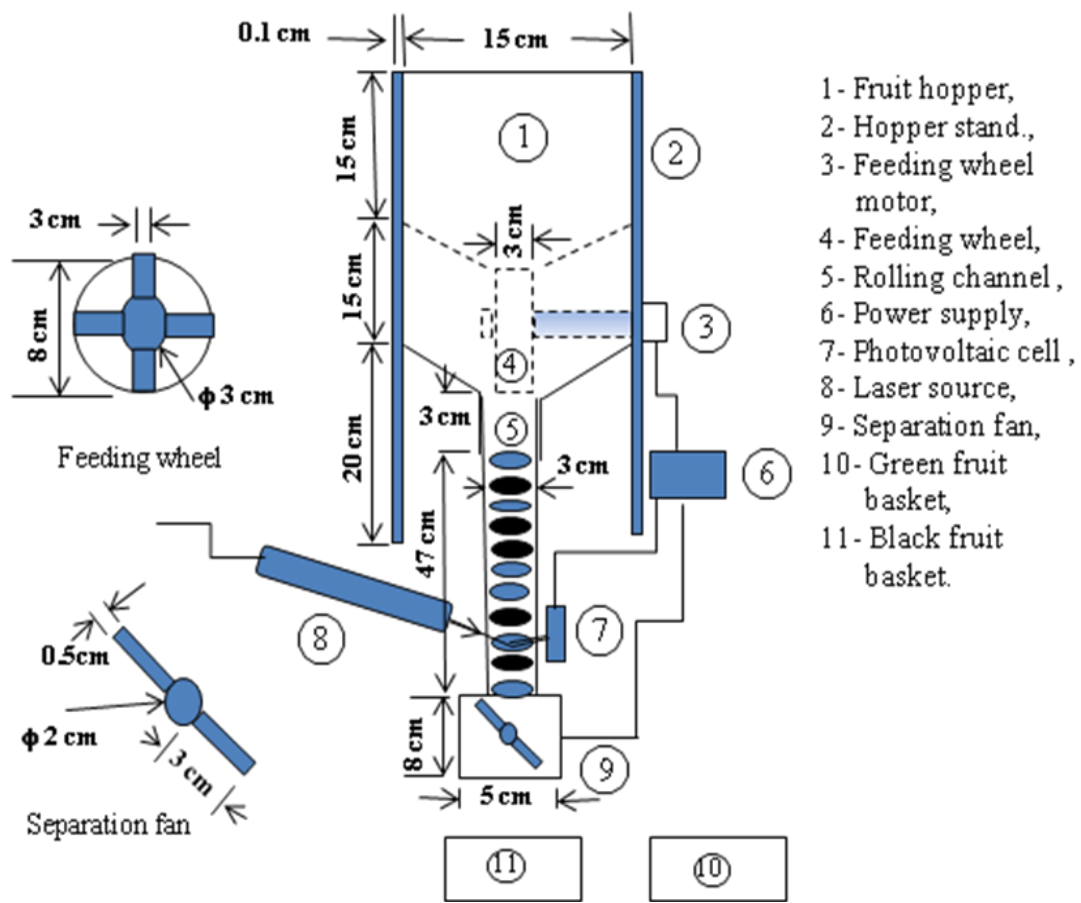

a) Schematic diagram of sorting unit.

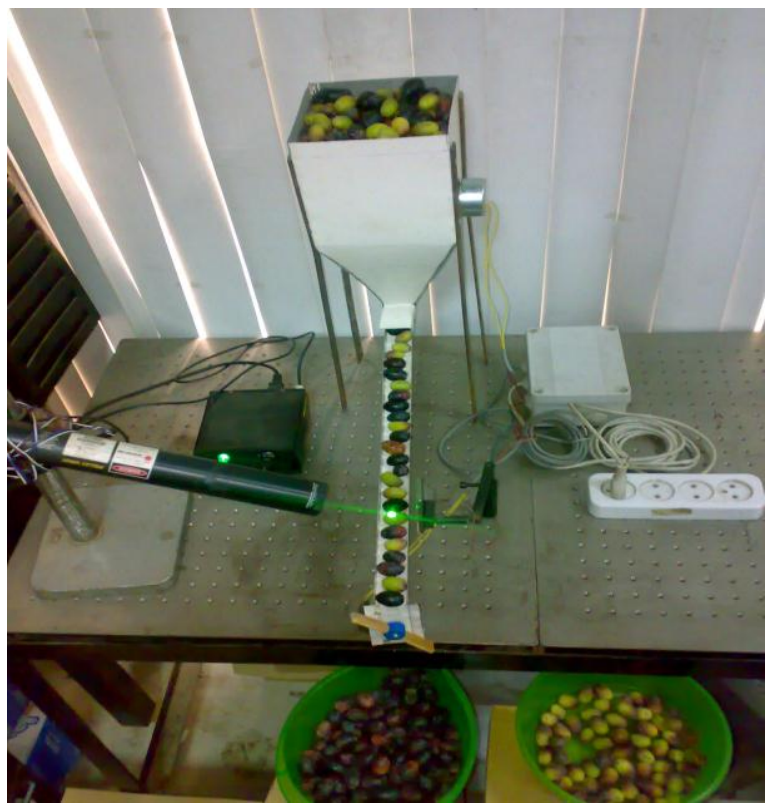

b) Photo of sorting unit.

Fig. (3) : Schematic diagram and photo of sorting unit for olive fruits. 


\section{RESULTS AND DISCUSSIONS}

Table (4): shows some main the physical properties of olive maturity. It was noticed that the values ranged between $(2.3-3.3 \mathrm{~cm}),(1.7-2.1$ $\mathrm{cm}),\left(2.5-4.1 \mathrm{~cm}^{3}\right),(3.1-5.5 \mathrm{~g})$, and $\left(0.756-1.774 \mathrm{~g} / \mathrm{cm}^{3}\right)$ for length, width, volume, mass, and density, respectively. Meanwhile, the average values of physical properties were $2.68 \mathrm{~cm}, 1.84 \mathrm{~cm}, 3.375 \mathrm{~cm}^{3}$, $4.155 \mathrm{~g}$, and $1.259 \mathrm{~g} / \mathrm{cm}^{3}$ for length, width, volume, mass, and density, respectively.

From the previous results, it possible to build fruit transporters of the prototype from the feeding wheel in the hopper and then feeding channel to transport to separation place, according to the greatest length of the olive $(3.3 \mathrm{~cm})$ and lowest width $(1.7 \mathrm{~cm})$ of olive to high sides of transporter channel to expose the fruit to laser beam. In order to move fruit easily, without any friction between fruit surface and metal surfaces of transporter parts. Therefore there is no damage of fruit during separating operation.

Table (4): Some physical properties of olive fruits

\begin{tabular}{|l|r|r|r|r|r|}
\hline Items & $\begin{array}{l}\text { Length, } \\
\text { cm }\end{array}$ & $\begin{array}{l}\text { Width, } \\
\mathrm{cm}\end{array}$ & $\begin{array}{l}\text { Volume, } \\
\mathrm{cm} 3\end{array}$ & $\begin{array}{l}\text { Mass, } \\
\mathrm{gm}\end{array}$ & $\begin{array}{l}\text { Density, } \\
\mathrm{g} / \mathrm{cm} 3\end{array}$ \\
\hline Min & 2.3 & 1.7 & 2.5 & 3.1 & 0.756 \\
\hline Max & 3.3 & 2.1 & 4.1 & 5.5 & 1.774 \\
\hline Average & 2.68 & 1.84 & 3.375 & 4.155 & 1.259 \\
\hline
\end{tabular}

Table (5): shows angle and coefficient of friction between olive fruits and different surfaces. It was noticed that the values of fraction angle of friction ranged between $\left(7.0-9.0^{\circ}\right),\left(5.0-8.0^{\mathrm{O}}\right),\left(4.5-9.0^{\mathrm{O}}\right),(7.0-$ $9.5^{\mathrm{O}}$ ), and $\left(4.0-7.0^{\mathrm{O}}\right.$ ) for galvanized sheet, iron sheet, fiber sheet, plastic sheet and wood sheet, respectively. Meanwhile, the average values of angle of friction was $8.28^{\mathrm{O}}, 6.46^{\mathrm{O}}, 6.67^{\mathrm{O}}, 8.18^{\mathrm{O}}$, and $5.13^{\mathrm{O}}$ for galvanized sheet, iron sheet, fiber sheet, plastic sheet and wood sheet, respectively.

The coefficient of friction ranged between $(6.32-8.13),(7.09-11.49)$, $(6.32-12.65),(5.98-8.13)$, and $(1.14-14.49)$ for galvanized sheet, iron sheet, fiber sheet, plastic sheet and wood sheet, respectively. 
Meanwhile, the average values of fraction factor were 6.86, 8.75, 8.76, 6.99, and 11.27 for galvanized sheet, iron sheet, fiber sheet, plastic sheet and wood sheet, respectively.

From previous results, the fruit transport from feeding hopper to separation place was constructed by friction angle about $9^{\mathrm{O}}$ at friction factor of 6.86 when using iron sheet in industrial fruit transport, to pass olive fruit with suitable speed $(2$ second $/ 50 \mathrm{~cm})$ on transporter channel with less fraction between olive fruit and surface of transporter. So, there is no damage of fruit during separating operation.

Table 5: Friction angle and factor of olive fruits on different surface materials

\begin{tabular}{|l|c|c|c|}
\hline \multirow{2}{*}{ Items } & \multicolumn{3}{|c|}{ Galvanized sheet } \\
\cline { 2 - 4 } & $\begin{array}{c}\text { Angle, } \\
\text { degree }\end{array}$ & $\begin{array}{c}\text { Tan } \theta, \\
\text { value }\end{array}$ & $\begin{array}{c}\text { Friction } \\
\text { coefficient }\end{array}$ \\
\hline Min & 7.000 & 0.123 & 6.329 \\
\hline Max & 9.000 & 0.158 & 8.130 \\
\hline Average & 8.283 & 0.147 & 6.860 \\
\hline Min & \multicolumn{3}{|c|}{ Iron sheet } \\
\hline Max & 5.000 & 0.087 & 7.092 \\
\hline Average & 8.000 & 0.141 & 11.494 \\
\hline & 6.467 & 0.116 & 8.756 \\
\hline Min & \multicolumn{3}{|c|}{ Fiber sheet } \\
\hline Max & 4.500 & 0.079 & 6.329 \\
\hline Average & 9.000 & 0.158 & 12.658 \\
\hline & 6.767 & 0.119 & 8.763 \\
\hline Min & 7.000 & 0.123 & 5.988 \\
\hline Max & 9.500 & 0.167 & 8.130 \\
\hline Average & 8.183 & 0.144 & 6.999 \\
\hline & \multicolumn{3}{|c|}{ Wood sheet } \\
\hline Min & 4.000 & 0.069 & 1.149 \\
\hline Max & 7.000 & 0.870 & 14.493 \\
\hline Average & 5.133 & 0.116 & 11.277 \\
\hline
\end{tabular}

Table (6) and Fig. (1) show the optical properties of olive fruits maturity using visible laser with $543 \mathrm{~nm}$ and power $8 \mathrm{mV}$. It was noticed that the 
intensity of reflection light from different surfaces of olive maturity ranged (20 - 25 lux), (26 - 33 lux), and (34 - 38 lux) for black, purple, and green of olive fruits, respectively. Meanwhile, the intensity of absorption light in different olive maturity was ranged (4275 - 4280 lux), (4267 - 4274 lux), and (4262 - 4266 lux) for black, purple, and green of olive fruits, respectively.

Also, table (6) shows the average of the reflected light intensity from different surfaces of olive maturity. The average reflection light intensities were 22.3, 28.9, and 35.2 lux for black, purple, and green olive fruits, respectively. Meanwhile, the average absorption lights for different olive maturities were 4277.7, 4271.1, and 4264.8 lux for black, purple, and green olive fruits, respectively.

Fig. (4) shows the average percentages of the reflection light intensity from different surfaces of olive maturity. The average percentages of the reflection light intensities were $0.52,0.67$, and $0.82 \%$ for black, purple, and green olive fruits, respectively. Meanwhile, the average absorption light intensities on different surface of olive maturities were 99.48, 99.33, and $9918 \%$ for black, purple, and green olive fruits, respectively. Generally, the absorption light intensity is very higher than reflection light intensity.

From the previous results, it is seen that the highest percentages of reflection light intensities were $0.82 \%$ for surface green olive fruit. Meanwhile, the lowest percentage of reflection light intensity was $0.52 \%$ for surface black olive fruit. So, the sorting prototype was based on 0.82 percentage of reflection light intensity from green surface as a measuring for sorting green olive from olive maturity fruit. This means that it is possible to sort mature olive according to color.

Table (6): Optical properties of olive fruits.

\begin{tabular}{|l|c|c|c|c|c|c|}
\hline \multirow{2}{*}{$\begin{array}{l}\text { Olive } \\
\text { color }\end{array}$} & \multicolumn{2}{|c|}{ Reflection intensity, Lux } & \multicolumn{3}{c|}{ Absorption intensity., Lux } \\
\cline { 2 - 7 } & Range & Average & Ref.,\% & Range & Average & Abso.,\% \\
\hline Black & $20-25$ & 22.3 & 0.52 & $4280-4275$ & 4277.70 & 99.48 \\
\hline Purple & $26-33$ & 28.9 & 0.67 & $4274-4267$ & 4271.10 & 99.33 \\
\hline Green & $34-38$ & 35.2 & 0.82 & $4266-4262$ & 4264.80 & 99.18 \\
\hline
\end{tabular}


Table (7) and Fig. (5) show that the average reflection light intensity and electrical signals, which resulted from transformation reflection light, from different surfaces of olive maturity. The average reflection light intensities were 22.3, 28.9, and 35.2 lux. Meanwhile, the electrical signals were 14.6, 19.1 and $23.9 \mathrm{mV}$ for black, purple, and green olive fruits, respectively.

From the previous results, it is seen that the highest electrical signal of reflection light from surface of green olive fruit was $23.9 \mathrm{mV}$ Meanwhile, the lowest electrical signals of reflection light intensity from surface of black olive fruit was $14.6 \mathrm{mV}$. So, the sorting prototype was based on equal or more than $22.4 \mathrm{mV}$ electrical signal resulting from reflection light from green surface as a measurement for sorting green olive from mature olive fruit.

Table (7): Relationship between the optical and electrical reflections from surface of olive fruits.

\begin{tabular}{|l|c|c|c|c|c|c|}
\hline \multirow{2}{*}{$\begin{array}{l}\text { Olive } \\
\text { color }\end{array}$} & \multicolumn{3}{|c|}{ Ref., Lux } & \multicolumn{3}{c|}{ Ref., mV } \\
\cline { 2 - 7 } & Min. & Max. & Average & Min. & Max. & Average \\
\hline Black & 20 & 25 & 22.3 & 13.3 & 16.9 & 14.6 \\
\hline Purple & 26 & 33 & 28.9 & 17 & 22.1 & 19.1 \\
\hline Green & 34 & 38 & 35.2 & 22.4 & 25.4 & 23.9 \\
\hline
\end{tabular}

Table (8): shows the relation between converting time of reflection light into electrical signals to operate separation fan at feeding rate of 394 $\mathrm{g} / \mathrm{min}$. The three positions of laser beam at different distances of 5,7 , and $9 \mathrm{~cm}$, gave separation efficiency 84,95 , and $89 \%$, respectively. So, the position (2) of $7 \mathrm{~cm}$ for laser as a source light gave the highest separation efficiency $95 . \%$.

Table (8): Effect of operating times of electrical signals and separating fan on sorting efficiency.

\begin{tabular}{|l|c|c|}
\hline Position no. & $\begin{array}{l}\text { Distance between the beam } \\
\text { and separation fan, cm }\end{array}$ & $\begin{array}{l}\text { Sorting efficiency, } \\
\%\end{array}$ \\
\hline 1 & 5 & 84 \\
\hline 2 & 7 & 95 \\
\hline 3 & 9 & 89 \\
\hline
\end{tabular}



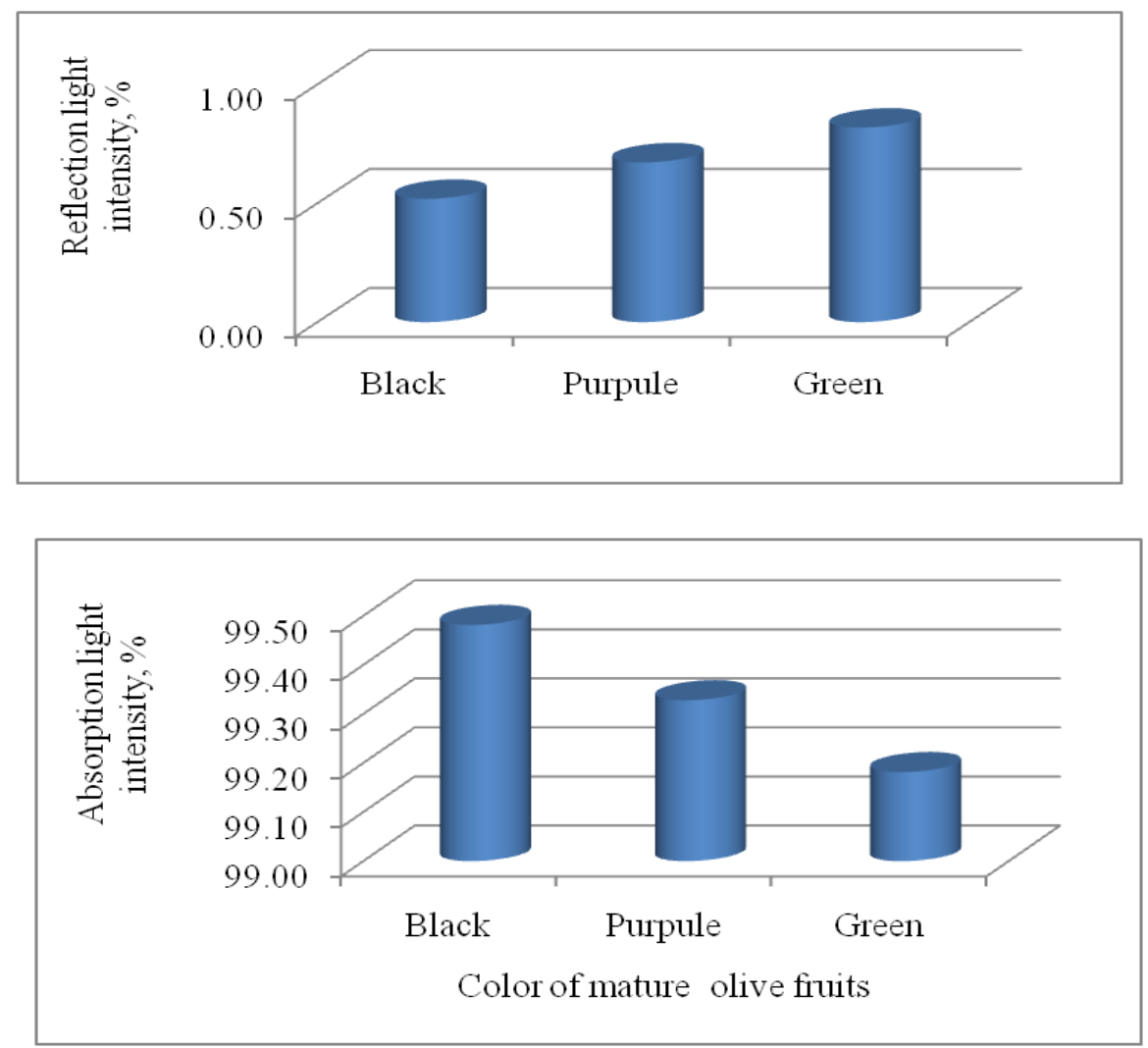

Fig. (4) : Reflection and absorption light percentage from surface of mature olive fruit.

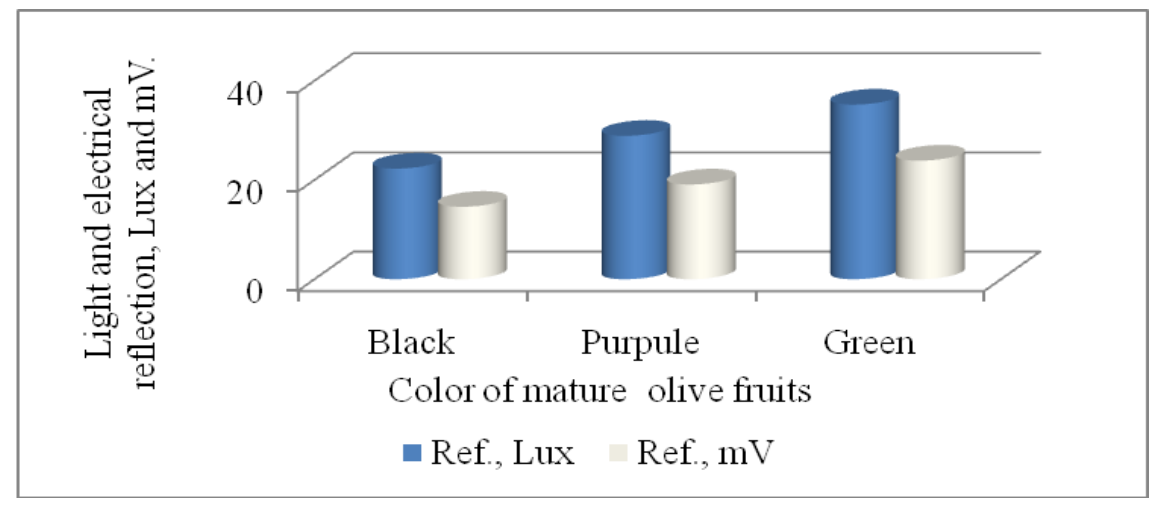

Fig. (5): Reflection light and electrical signal of mature olive fruit. 
Table (9) shows the performance rate of sorting prototype of mature olive fruits using laser. It is noticed that the feeding rates were 131.53, 263.17, 394.61, 526.15, and $146.15 \mathrm{~g} / \mathrm{min}$. at operation time was 15.20, 7.60, 5.07, 3.80, and $13.68 \mathrm{~min}$., that gave separating efficiency 99, 96, 65, 81, and $97 \%$, for four uses of prototype and one manual time, respectively.

From the previous results, it is preferable to use feeding rate of 394.61 $\mathrm{g} / \mathrm{min}$ during operating time $5.07 \mathrm{~min}$, because this gave the lowest cost of operating unit in comparison with other costs of operating unit of prototype with separating efficiency $95 \%$. Yet, separation efficiency of the manual operation of $96 \%$ is higher than separating efficiency of $95 \%$ of prototype. Cost of operating unit of the manual operation of 0.85 L.E. is lower than the cost of operating unit of the prototype 1.39 L.E. However, the working time of prototype of $5.07 \mathrm{~min}$ is lower than of working time of manual operation of 13.68 min., and manual sorting contains personal error. That means that efficiency of separating prototype is acceptable using laser beam on mature olive fruit.

Table (9): Performance of sorting prototype for olive fruits.

\begin{tabular}{|l|c|c|c|c|c|}
\hline \multirow{3}{*}{ Methods } & \multicolumn{2}{|c|}{ Feeding rate } & $\begin{array}{c}\text { Working } \\
\text { time, } \\
\text { min }\end{array}$ & $\begin{array}{c}\text { Cost } \\
\text { operating } \\
\text { unit, L.E./Kg }\end{array}$ & $\begin{array}{c}\text { Sorting } \\
\text { efficiency } \\
\%\end{array}$ \\
\cline { 2 - 6 } & Olive no. & $\mathrm{g} / \mathrm{min}$ & & & \\
\hline Prototype & 36 & 131.538 & 15.20 & 4.12 & 99 \\
\cline { 2 - 6 } & 72 & 263.077 & 7.60 & 2.08 & 96 \\
\cline { 2 - 6 } & 108 & 394.615 & 5.07 & 1.39 & 95 \\
\cline { 2 - 6 } & 144 & 526.154 & 3.80 & 1.04 & 81 \\
\hline Manual & 40 & 146.154 & 13.68 & & $96^{*}$ \\
\hline
\end{tabular}

* This value depends on the personal accuracy.

\section{CONCLUSION}

The obtained results are as follows:

(1) The greatest length of the olive is $(3.3 \mathrm{~cm})$ and the least width $(1.7$ $\mathrm{cm}$ ) of olive, to estimate the width and height sides of transporter channel to suit exposure of the fruit to laser beam., 
(2) The fruit transporter channel from feeding hopper leading to separation place by friction angle about $9^{\mathrm{O}}$ at friction factor of 6.86 when using iron sheet according to friction factor between olive fruit and surface of transporter.,

(3) The highest and lowest percentages of reflection light were $0.82 \%$ and $0.52 \%$ for green surface and black olive fruit, respectively. So, the sorting prototype was based on $0.82 \%$ reflection for sorting green olive from olive maturity fruit.

(5) The highest and lowest electrical signals resulting from reflection light intensity were 23.9 and $14.6 \mathrm{mV}$ for green and black olive fruit, respectively. So, the sorting prototype depends on equal and more than $22.4 \mathrm{mV}$ of electrical signals for sorting green olive from mature olive fruit.,

(6) It is preferable that the to use feeding rate of $394.61 \mathrm{~g} / \mathrm{min}$ during operating time $5.07 \mathrm{~min}$, because it gave the lowest cost of operating unit in comparison with other costs of operating unit of prototype with separating efficiency of $95 \%$.

(7) Separation efficiency of manual sorting was $96 \%$ which is higher than separating efficiency $95 \%$ of prototype, and cost of operating unit of manual operation of 0.85 L.E. which is lower than cost of operating unit of prototype of 1.39 L.E. However, working time of prototype of 5.07 min is lower than working time of manual operation of 13.68.,

(8) Laser technique can be used as a sorting (external quality evaluation) for olive fruits with accuracy.

Acknowledgement: We would like to express our deepest gratitude and thanks to Assistant. Prof. Dr. Ayman Abo El-magd, Laser Physics and electronics, for constructing power supply of sorting unit.

\section{REFERENCES}

Abbott, J. A. (1999). Quality measurements of fruits and vegetables. Posthar Vest Biol. Tech., 15, 207-225.

Awady, M. N. (1978) Tractors and farm machine (in Arabic), text. Col. Ag., Ain Shams Univ.; 164-167.

Diaz R., L. Gil, C. Serrano, M. Blasco, E. Molto and J. Blasco (2004). Comparison of three algorithms in the classification of 
table olives by means of computer vision. J. of Food Eng., 61: 101107.

Garc M.J.L., J.M. H.Martnez, G. R.Ramos and E.F. S. Alfonso (2008). Evaluation of the quality of olive oil using fatty acid profiles by direct infusion electrospray ionization mass spectrometry. Dep. Analy. Chem., Fac. Chem., Un. Valencia, Spain. Food Chem. 107 : 1307-1313.

García J. M., S. Seller and M. C. Pérez-Camino. (1996). Influence of fruit ripening on olive oil quality. J. Agric. Food Chem. 1996, 44, 3516-3520.

Giovanni A., P. Pinelli, S. C. E.bner, A. Romani, A. L. Cartelat and Z. G. Cerovic (2005). Nondestructive evaluation of anthocyanins in olive (Olea europaea) fruits by in Situ Chlorophyll Fluorescence Spectroscopy. J. Agric. Food Chem. 53: 1354-1363

Hassan, H. E.; A. A. Abd El-Rahman and M. M. Attia (2011). Laser classification of olive fruits during maturity according to optical properties. Misr J. of Agric. Eng., 28 (3): 686 - 700.

Jaakola L., K. Maatta, A. M. Pirttila, R. Torronen, S. Karenlampi and A. Hohtola (2002). Expression of genes involved in anthocyanin biosynthesis in relation to anthocyanin, proanthocyanidin, and flavonol levels during bilberry fruit development. Plant Physiol. Pp. 130, 729-739.

Jia X., J. J. Cui, D. Y. Xue and F. Pan. (2012). An adaptive Dorsal Hand Vein recognition algorithm based on optimized HMM. J. Comp. Inf. Syst. : $313-322$.

Jose A. C. and M. C. P. Camino (2010). Prediction of quality parameters of intact olives by near infrared spectroscopy. Dep. Physio. and Tech. Plant Prod. Dep. Food Quality and Character.,la Grasa-CSIC., Spain. Europ. J. of Lipid Sc. and Tech. : 1-23

Leon L., A. Garrido and G. Downey (2004). Parent and harvest year effects on near-infrared reflectance spectroscopic analysis of olive 
(Olea europaea L.) Fruit Traits. J. Agric. Food Chem. 52: 49574962.

Loudiyi W.D., M. Chmitah, R. Loussert, A. Mahhou and B. Boulouha (1984). Morphologic and physiologic characters of olive clones from Picholine Marroqui variety. Olivae, 3: 26-31.

Mulinacci N., A. Romani, P. Pinelli, C. Galardi, K. Giaccherini and F. F. Vincieri (2001). Polyphenolic content in olive oil wastewaters and related olive samples. J. Agric. Food Chem., 49: 3509-3514.

Nicolai B. M., K. Beullens, E. Bobelyn, A. Peirs, W. Saeys, K. Theron and J. Lammertyn. (2007). Nondestructive measurement of fruit and vegetable quality by means of NIRS spectroscopy: A review. Postharvest Biol. Technol. 46: 99-118.

Ounis A., Z. G. Cerovic, I. Moya, and J. M. Briantais (2001). Dualexcitation FLIDAR for the estimation of epidermal UV absorption in leaves and canopies. Remote Sens. EnViron., 76: 3348.

Peter B., C. Hofmann and B. Tauscher (2005). Recent developments in noninvasive techniques for fresh fruit and vegetable internal quality analysis. J. of Food Sc. 70(9): 131-141.

Psomiadou E., and M. Tsimidou (2001). Pigments in Greek virgin olive oils: occurrence ., 3(2): 125-136

Riquelme M.T., P. Barreiro, M. R. Altisent and C. Valero (2008). Olive classification according to external damage using image analysis. J. Food Eng. 87: 371-379

Roca, M. and M. I. Minguez-Mosquera (2001). Change in the natural ratio between chlorophylls and carotenoid in olive fruit during processing for virgin olive oil. J. Am. Oil Chem. Soc., 78: 133138.

Ryan D., M. Antolovich. P.D. Prenzler, K. Robards andS. Lavee (2002). Biotransformations of phenolic compounds in Olea europaea L. Sci. Hortic. 2002, 92, 147-176. 


\section{PROCESS ENGINEERING}

\section{الملخص العربي \\ فرز ثمار الزيتون باستخدام الليزر المرئح طبقا للون \\ حلمى السيد حسن " حن}

تهدف الدر اسة لإستخدام تقنيات الليزر المرئى ذى الدقة العالية فى قياس وتحديد الخصائص الفيزيائية والبصرية و الكهربائية لثمار الزيتون الناضجة باستخدام الليزر المرئي، وذلك لتصنيع فئي

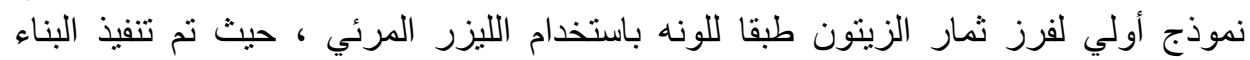

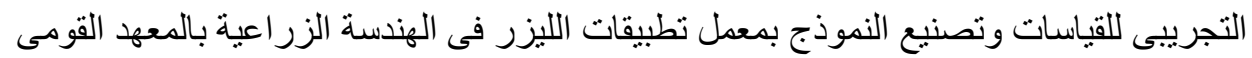

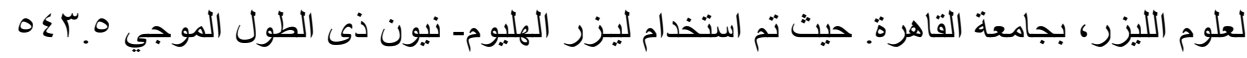

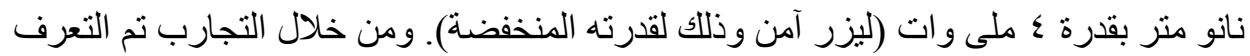

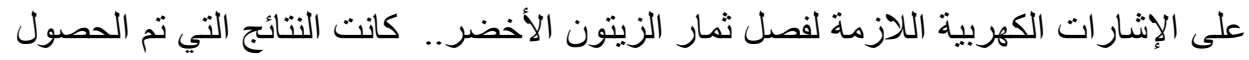
عليها على النحو التالي:

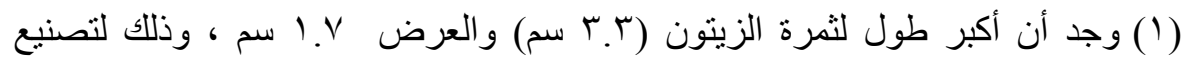

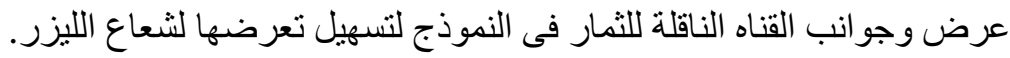

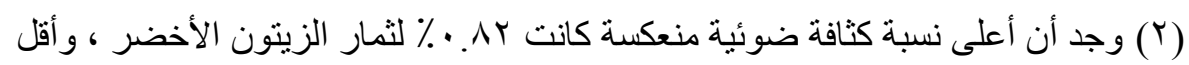

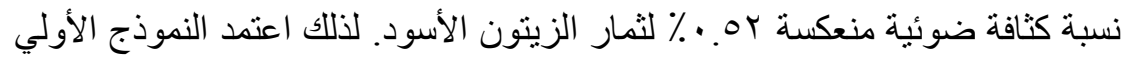

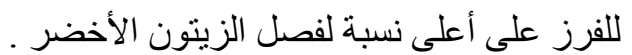

(T) وجد أن أعلى إشارة كهربائية ناتجة من الكثافة الضوئية المنعكسة من ثمار الزيتون

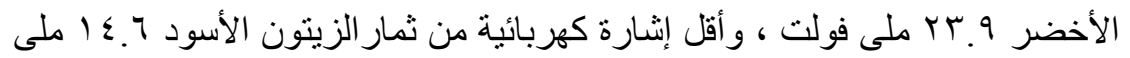

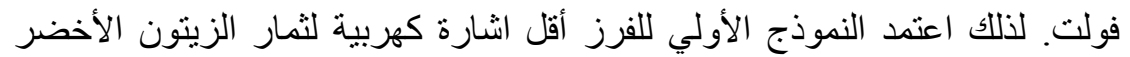
ع. Y ب بالملى فولت باعتبار ها مقياس لبداية عملية الفرز بعد تكبيير هذه الأشارة .

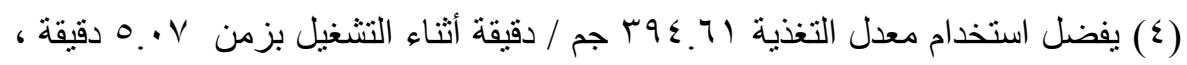
حيث يعطى التشغيل أقل تكلفة للفرز مقارنة بوحدة التكاليف الأخرى لتشغيل النموذج وكفاءة تنثغيل مناسبة.

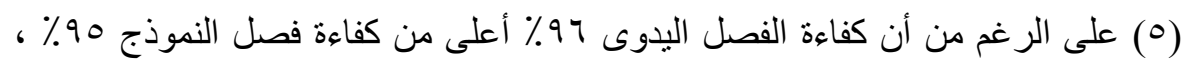

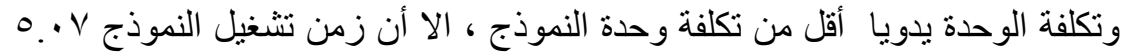

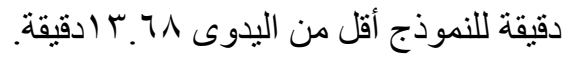

(7) وجد أن كفاءة فصل النموذج مقبولة وذات دقه عالية باستخدام شعاع الليزر لفرز ثمار الزيتون الناضجة على نطاق كبير وبدقة عالية.

* أستاذ مساعد تطبيقات الليزر فى الهندسة الزراعة ــ المعهد القومى لعلوم الليـزر- جامعـة

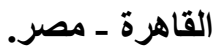

